\title{
A CASE REPORT ON A PATIENT WHOSE ROAD TRAFFIC INJURY SEVERITY WAS DETERMINED BY THE MAIS (MAXIMUM ABBREVIATED INJURY SCALE) SCORE
}

\author{
Goran Colakovic, Sladjana Andjelic
}

Institute for Urgent Medical Care, Belgrade, Serbia

\section{PRIKAZ BOLESNIKA KOME JE TEŽINA TELESNE POVREDE ZADOBIJENE U SAOBRAĆAJNOJ NEZGODI PROCENJENA MAIS (MAXIMUM ABBREVIATED INJURY SCALE) SKOROM}

\author{
Goran Čolaković, Slađana Anđelić
}

Gradski zavod za hitnu medicinsku pomoc Beograd, Srbija

\begin{abstract}
There are numerous definitions and classifications of severe trauma. Due to the observed heterogeneity in the existing definitions and the lack of a uniform definition of serious bodily injury, in January 2013 the High Level Group on Road Safety EU (HLGRS) published the definition of serious bodily injury in road traffic as a non-fatal injury with Maximum Abbreviated Injury Scale (MAIS) between 3 and 6, including the limit values. However, determining the MAIS score is not easy even for doctors with many years of experience. A female patient, injured as a pedestrian in a traffic accident, was examined prehospitally, and was transported to the hospital in the optimal golden hour from the time of the injury. The patient was intubated and mechanically ventilated in the Critical Care Resuscitation Unit. After the entire diagnostic procedure, diagnoses were made according to the ICD classification of diseases. During further examination, each code of the diagnosis of the disease was assigned an AIS code and the highest AIS score - AIS 5 was determined, which indicated that the patient was critically injured. Our patient's MAIS score was 5. After 39 days she was discharged from hospital. The neurological findings at discharge corresponded to left hemiparesis - ASIA $D$ impairment grade. In conclusion, a novelty in the assessment of severe bodily injury is the introduction of the AIS/MAIS score. However, to avoid a subjective assessment of these scores, AIS dictionaries should be obtained for physicians, or a software solution should be developed to convert ICD-10 diagnoses into the AIS / MAIS injury scale.
\end{abstract}

Key words: pedestrian, severe trauma, ICD-10, AIS score, MAIS score.

\section{SAŽETAK}

Mnogobrojne su definicije i klasifikacije teške traume. Zbog uočene heterogenosti u postojećim i nedostatku jedinstvene definicije teške telesne povrede, u januaru 2013., High Level Group on Road Safety EU (HLGRS) objavljuje definiciju teške telesne povrede u drumskom saobraćaju kao nesmrtne povrede sa Maximum Abbreviated Injury Scale (MAIS) od 3 do 6 uključujući i granične vrednosti. Međutim, određivanje MAIS skora nije jednostavno čak ni lekarima sa višegodišnjim iskustvom. Pacijentinja povređena kao pešak u saobraćajnoj nezgodi, pregledana prehospitalno, transportovana je u bolnicu u optimalnom zlatnom satu od trenutka povređivanja. Na odeljenju reanimacije, pacijentkinja je intubirana i mehanički ventilirana. Nakon celokupne dijagnosticke obrade, postavljene su dijagnoze prema MKB klasifikaciji bolesti. Tokom dalje egzaminacije, svakoj šifri dijagnoze bolesti, dodeljen je AIS kod i određen kao najveći AIS skor - AIS 5, koji je označio da se radi o kritično povređenoj osobi. MAIS skor naše pacijentkinje je bio 5. Nakon 39.dnevne hospitalizacije otpuštena je kući. Neurološki nalaz na otpustu odgovara levostranoj hemiparezi - ASIA D stepen oštećenja. U zaključku, novina u proceni teške telesne povrede je uvođenje AIS/MAIS skora. Međutim, da bi se izbegla subjektivna procena ovih skorova, lekarima bi trebalo nabaviti AIS dictionary, ili prirediti softversko rešenje za prevođenje MKB-10 dijagnoza u AIS/MAIS skalu povreda. skor.

Ključne reči: pešak, teška trauma, MKB-10, AIS skor, MAIS 


\section{INTRODUCTION}

Road traffic injuries are currently the eighth leading cause of death in the world, with an impact similar to that of infectious diseases. According to current trends, they are assumed to become the fifth leading cause of death by 2030, with a clear difference in distribution between high- and low-income countries (1). According to the World Health Organization (WHO), every year tens of millions of people are injured in road traffic globally, with over 1.3 million deaths, which means that one person dies in traffic every 25 seconds (1). The Traffic Safety Agency statistical data for 2019 show that 20,390 people were injured on the territory of the Republic of Serbia, of which 17,068 slightly and 3,322 severely, and a total of 534 people were killed (2).

There are numerous definitions and classifications of severe trauma. Thus, traffic police classify injuries as fatal injury, severe bodily injury (SBI) and minor bodily injury (MBI) (3). In the current medical literature, severe or major trauma is defined as ,traumatic extensive damage to an organ or organ system which can potentially endanger other organs or organ systems in anatomic and/or functional manner and can result in the death of the patient" (4). During the development of the SafetyNet program, it seemed that the definition would most likely read that it was a person who had spent more than 3 days in hospital, which is why the term hospitalized person was suggested (5).

Due to the observed heterogeneity in the existing definitions and the lack of a uniform definition of serious bodily injury, in January 2013 the High Level Group on Road Safety EU (HLGRS) published the definition of serious bodily injury in road traffic as a non-fatal injury with Maximum Abbreviated Injury Scale (MAIS) between 3 and 6, including the limit values. However, determining the MAIS score is not easy even for doctors with many years of experience.

We present a case of a female patient whose bodily injuries sustained in a road traffic accident were assessed by using the MAIS score.

\section{CASE REPORT}

On 20 October 2020 at 15:37, 194 Call Center received an emergency call by the police about a traffic accident in which a pedestrian was injured. The ambulance team accepted it as a Category 1 call at 15:39. Upon the arrival at the scene at 15:48, the emergency team finds an unconscious woman aged about 60, Glasgow coma score (GCS) 3, Revised trauma score (RTS) 3, hemodynamically stable (TA $120 / 71 \mathrm{mmHg}, \mathrm{Hr} 78 / \mathrm{min}$ ) with polytraumatic injuries. Two intravenous lines and an oropharyngeal airway were placed. The patient was prepared for transport and with ambu balloon ventilation with an oxygen tank, the team left the scene at 15:57. At 4:04 p.m., the patient was handed over to the Intensive Care Unit of the Emergency Center. At 16:04 the EMS ambulance team was free for the next call. The emergency response time of the EMS team is shown in Figure 1.

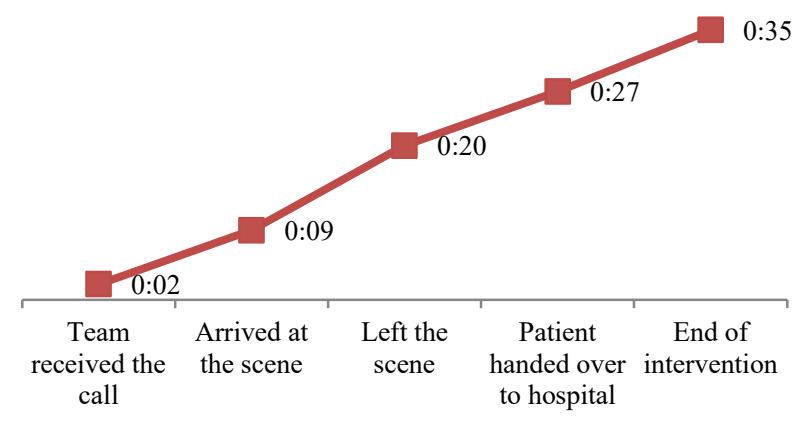

Figure 1. The emergency response time of the EMS team

The patient was intubated and mechanically ventilated in the Critical Care Resuscitation Unit. She was clinically examined and laboratory tests, MSCT and X-ray were performed. At the MSCT of the endocranium, frontoparietal SAH was observed bilaterally above convexity. The chamber system was of regular position and dimensions. Neurological findings revealed right-sided paraplegia corresponding to the neurological findings of ASIA (The American Spinal Injury Association) A impairment scale (7): complete impairment, no motor or sensory function preserved in the sacral segments S4-S5.

The following diagnoses were made according to ICD 10 classification:

V02.0 Pedestrian injured in collision with two- or three-wheeled motor vehicle

T07 Laesiones traumataicae mutiplices, non specificatae

S00 Contusio cerebri

S06.5 Haemorrhagia subduralis traumatica (SAH).

S22.0 Fractura vertebrae thoracalis Th4 et Th5

G82.2 Paraplegia/Haemiparesis 1. sin. (ASIA -D)

S22.3 Fractura costae VIII. sin

S52.0 Fractura ulnae pars prox. 1. sin.

S82.1 Fractura pars proximalis fibiae multifragmentaris I. sin.

S32.5 Fractura ossis pubis rami inferior et superior 1. $\sin$.

S32.1 Fractura ossis sacri 1. sin.

During further examination, each code of the diagnosis of the disease was assigned an AIS code and the AIS score was determined (Table 1)

Table 1. Determining AIS scores in our patient

\begin{tabular}{|l|l|c|}
\hline \multicolumn{1}{|c|}{ Diagnosis code } & \multicolumn{1}{c|}{ AIS code } & AIS score \\
\hline T07 & 9150.5 & 5 \\
\hline S00 & 1104.1 & 1 \\
\hline S06.5, G82.2 & 1404.5 & 5 \\
\hline
\end{tabular}




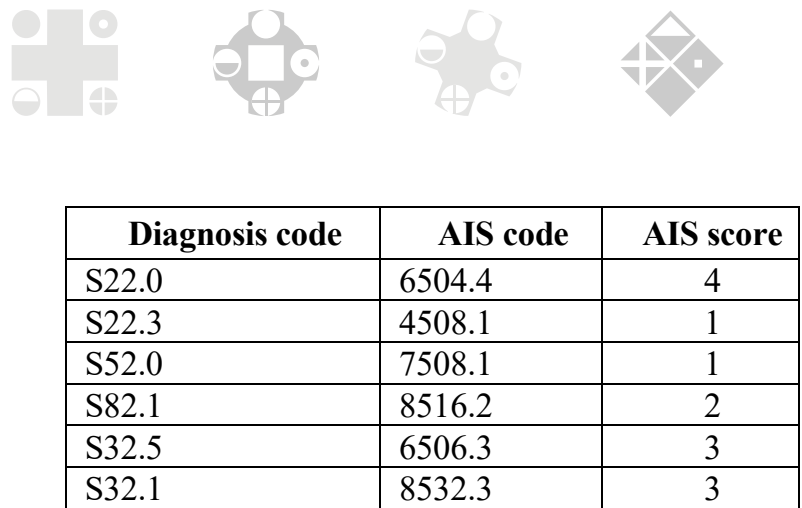

The maximum AIS (MAIS) score was 5.

The patient was admitted to the Intensive Care Unit, where she received AT protection, polyvalent antibiotic, analgesic, anticoagulant and all relevant anesthesia therapy. She was extubated on the twenty-fourth day of hospitalization and transferred to the Spinal Surgery Department.

The patient was discharged from hospital two weeks later. The neurological findings at discharge correspond to left-sided hemiparesis - ASIA D impairment level (incomplete impairment, motor function preserved below the neurologic level).

\section{DISCUSSION}

According to the Traffic Safety Agency statistical data for 2019 (2), the distribution of casualties in road traffic accidents was as follows: motor vehicle drivers come first (45\%), followed by passengers $(34 \%)$, while pedestrians (like our patient) are in third place (14\%). In Reported Road Casualties Great Britain: 2015 annual report (8), the number of severely $($ MAIS3 + ) injured road traffic participants in England and the UK in 2011 was over 5,000, with over $70 \%$ pedestrians.

Trauma is a time-sensitive condition, so the time of care and transport of a severely injured person at the pre-hospital level is limited. The time of arrival of the ambulance team to the injured person, the time of examination and care at the prehospital level, the time of transport of the injured person to an adequate hospital and final surgical care should be up to an hour and it is called the golden hour (9). The urgent response time of the EMS team in our case is shown in Figure 1. Every injured person requires a detailed examination both at the prehospital and hospital level with the application of available diagnostic tests, all with the aim of correct classification and qualification of the severity of the injury. At the international level, one of the oldest classification systems in health care is the International Classification of Diseases (ICD), developed on the basic model of classification of diseases, injuries and causes of death initially formulated in England. Today, the ICD represents the intellectual property of the WHO, which provides codes for the classification of diseases (10).

The ICD revisions currently in use are revisions 9 and 10, while road traffic accident injuries have special codes in "the external causes" section, as well as codes that describe injuries.
Scoring systems represent an attempt to objectify the assessment of the condition of severely injured and vitally endangered patients, and consist of scoring, i.e. numerical quantification of the severity of the injury (9). In clinical practice, several different trauma score systems are used to objectively assess the severity of injuries in traffic accidents, and most often, as in our patient, AIS (11) and MAIS scale (12).

The AIS coding system, established by the Association for the Advancement of Automotive Medicine (AAAM), is based on anatomical criteria and is used to quickly assess and classify the severity of an injury. In other words, AIS is a numerical representation of the anatomical severity of each injury. Table 2 illustrates the method of determining an AIS code composed of 7 digits [12 (34) (56) .7] which describes: body region (1), type of anatomical structure (2), specific anatomical structures (3-4), level (5-6) and injury severity score (7).

Table 2. The method of determining AIS (11)

\begin{tabular}{|c|c|c|c|}
\hline \multicolumn{2}{|c|}{ 1. Body region } & \multicolumn{2}{|c|}{$\begin{array}{l}\text { 2. Type of anatomic } \\
\text { structure }\end{array}$} \\
\hline $\begin{array}{l}\text { AIS } \\
\text { Code }\end{array}$ & Region & $\begin{array}{c}\text { AIS } \\
\text { Code }\end{array}$ & Region \\
\hline 1 & Head & 1 & Whole Area \\
\hline 2 & Face & 2 & Vessels \\
\hline 3 & Neck & 3 & Nerves \\
\hline 4 & Thorax & 4 & $\begin{array}{l}\text { Organs (inc. mus- } \\
\text { cles/ligaments) }\end{array}$ \\
\hline 5 & Abdomen & 5 & Skeletal (inc. joints) \\
\hline 6 & Spine & 6 & $\begin{array}{l}\text { Loss of Conscious- } \\
\text { ness (head only) }\end{array}$ \\
\hline 7 & Upper Extremity & & \\
\hline 8 & Lower Extremity & & \\
\hline 9 & Unspecified & & \\
\hline
\end{tabular}

\begin{tabular}{|c|l|}
\hline \multicolumn{2}{|c|}{ 3/4. Specific anatomic structure } \\
\hline \multicolumn{2}{|c|}{ Whole Area } \\
\hline AIS Code & Region \\
\hline 02 & Skin Abrasion \\
\hline 04 & Contusion \\
\hline 06 & Laceration \\
\hline 08 & Avulsion \\
\hline 10 & Amputation \\
\hline 20 & Burn \\
\hline 30 & Crush \\
\hline 40 & Degloving \\
\hline 50 & Injury - NFS \\
\hline 60 & Penetrating \\
\hline \multicolumn{2}{|c|}{ Head - Loss of Consciousness (LOC) } \\
\hline 02 & Length of loss of consciousness \\
\hline $04-08$ & Level of consciousness \\
\hline 10 & Concussion \\
\hline
\end{tabular}




\begin{tabular}{|c|l|}
\hline Spine & \\
\hline 02 & Cervical \\
\hline 04 & Thoracic \\
\hline 06 & Lumbar \\
\hline \multicolumn{2}{|c|}{ Vessels, Nerves, Organs, Bones, Joints } \\
\hline 02 & Vessels \\
\hline 04 & Nerves \\
\hline 06 & Organs \\
\hline 08 & Bones \\
\hline 10 & Joints \\
\hline \multicolumn{2}{|c|}{ 5/6 Level } \\
\hline $\begin{array}{l}\text { Specific Injuries are assigned consecutive two-digit num- } \\
\text { bers beginning with 02. } \\
\text { Fractures, rupture, laceration, etc. }\end{array}$ \\
\hline
\end{tabular}

The AIS scale contains two components: (1) the description of the injury (often referred to as "pre-dot code") is a unique numerical code of each injury; and (2) the severity of the injury (often referred to as "post-dot code"), ranging from 1 (minor) to 6 (non-survivable injury). Based on the AIS score, the following injury qualification is possible: minor injury (AIS1); moderate injury (AIS 2); serious injury (AIS 3); severe injury (AIS 4); critical injury (AIS 5); injury incompatible with life or fatal injury (AIS 6). An AIS-Code of 9 is used to describe injuries for which not enough information is available for more detailed coding (Table 3 ).
Table 3. Qualification of injury based on AIS score values

\begin{tabular}{|c|l|}
\hline AIS-score & \multicolumn{2}{c|}{ Injury } \\
\hline $\mathbf{1}$ & Minor \\
\hline $\mathbf{2}$ & Moderate \\
\hline $\mathbf{3}$ & Serious \\
\hline $\mathbf{4}$ & Severe \\
\hline $\mathbf{5}$ & Critical \\
\hline $\mathbf{6}$ & Maximum \\
\hline $\mathbf{9}$ & No futher specified (NFS) \\
\hline
\end{tabular}

The application of the AIS score is simple, the obtained numerical values are clearly defined, and scoring can be applied in the same way by any healthcare professional. There are two ways to determine AIS: (1) AIS can be coded directly by a trained medial professional, on the basis of available medical documentation on patient's injuries; and (2), as in our case, AIS can be converted from ICD 9 or ICD 10 classification. Our patient had the following AIS scores: 1, 3, 4, and 5. Nowadays, the European Center for Injury Prevention has developed various software packages for mapping AIS from ICD 9-10 (ICDmap90, ICDpic), ECIP and AAAM) (13).

Table 4. Presents methods of determining the AIS score in EU member countries (14)

\begin{tabular}{|l|l|}
\hline The Czech Republic & AIS score is derived from ICD 10 classification \\
\hline Germany & Determined by a physician \\
\hline France & $\begin{array}{l}\text { The medical diagnosis is directly encoded in the AIS score. This coding is performed by a } \\
\text { trained physician on the basis of all injuries described during hospitalization. }\end{array}$ \\
\hline The Netherlands & AIS score is derived from ICD 9 classification, using ICDmap90 \\
\hline Spain & $\begin{array}{l}\text { A software program converts ICD9-CM code into AIS: } \\
\text { - ICDMAP (Johns Hopkins University). } \\
\text { - ICDPIC: (Boston College Department of Economics). This is a STATA module designed } \\
\text { to convert the ICD9-CM diagnostic code into the standard category of injuries and / or scores. }\end{array}$ \\
\hline Great Britain & $\begin{array}{l}\text { Mapping from ICD-10 codes by using codes developed at the University of Navarra (Euro- } \\
\text { pean Centre for Injury Prevention, University of Navarra, Algorithm to transform ICD-10 } \\
\text { codes AIS and ISS, version 1 for SPSS. Pamplona, Spain 2006). }\end{array}$ \\
\hline
\end{tabular}

It is recommended that if a patient has multiple injuries, a separate AIS score should be determined for each injury, and finally their overall effect assessed and the injury qualified (15). Our patient had AIS scores ranging from 1 to 5, and the injury was classified as critical. According to the definition, MAIS is the maximum AIS score, which in our case was 5 .

A study Broughton et al. (16) discussed which MAIS score would most reliably define severe injury. As it is not always possible to accurately determine the MAIS1 and
MAIS2 scores, it has been suggested that MAIS3 represents the minimum reference value of the score indicating injury severity. Based on the opinions of the International Road Traffic and Accident Database - IRTAD (2010) (17) and HLGRS (18), since 2012 there has been a Recommendation at the EU level that the Abbreviated Injury Scale - AIS is used for the assessment of the severity of road traffic injuries, and MAIS $\geq 3$ for severe injuries.

Our patient had a severe bodily injury, and in accordance with that, adequate pre-hospital and hospital diagnostic and 
therapeutic procedures were applied. Due to the severity of the clinical picture and the injuries she sustained, the patient was hospitalized for a total of 39 days and discharged with ASIA D level of impairment.

In conclusion, a novelty in the assessment of severe bodily injury is the introduction of the AIS/MAIS score. However, to avoid subjective assessments of these scores, AIS dictionaries should be obtained for physicians, or a software solution should be developed to convert ICD-10 diagnoses into the AIS/MAIS injury scale. Prior to that, clinical physicians should be informed on the methods of determining the AIS/MAIS score on the basis of ICD-10 diagnoses codes in the hospitalization report.

\section{CONFLICT OF INTEREST}

Authors report no conflict of interest.

\section{FUNDING}

This paper has no funding source.

\section{REFERENCES}

1. World Health Organization. Global status report on road safety 2018: summary. Switzerland: Geneva, 2018.

2. Miljuš J (ur). Statistički izveštajo stanju bezbednosti saobraćaja uRepublici Srbiji u 2019. godini. Beograd: Agencija za bezbednost saobraćaja RS, 2020.

3. Amoros E, Martin JL, Lafont S, Laumon B. Actual incidences of road casualties, and their injury severity, modelled from police and hospital data, France. Eur J Public Health 2008; 18(4): 360-365.

4. Grba-Bujević M. Pristup politraumatizovanom pacijentu na terenu. U: Važanić D. (ur). Škola hitne medicine - 2. Modul: Trauma. Zagreb: Hrvatsko sestrinsko društvo hitne medicine, 2015

5. Reed S, Morris A. Building the European Road Safety Observatory. SafetyNet. Deliverable 5.5, Glossary of data variables for fatal and accident causation databases. London: Loughborough University, 2008.

6. ITF. Road Safety Annual Report 2018. Paris: OECD Publishing, 2018.

7. Kirshblum SC, Burns SP, Biering-Sorensen F, Donovan W, Graves DE, Jha A, et al. International standards for neurological classification of spinal cord injury (revised 2011). J Spinal Cord Med 2011;34(6):535-546.
8. Department for transport. Reported road casualties Great Britain: 2015 annual report: Estimating clinically seriously injured (MAIS3+) road casualties in the UK, 2016.

9. Jokšić-Mazinjanin R. Prehospitalni faktori i trauma skorovi za procenu težine traume i predviđanje ishoda lečenja povređenog pacijenta, doktorska disertacija. Novi Sad: Medicinski fakultet Univerziteta u Novom Sadu, 2018.

10. Međunarodna statistička klasifikacija bolesti i srodnih zdravstvenih problema. Deseta revizija, Knjiga 1. Beograd: Institut za javno zdravlje Srbije "Dr Milan Jovanović Batut", 2013.

11. Gennarelli TA, Wodzin E. (ed). The Abbreviated Injury Scale 2005 - Update 2008. Barrington, Illinois: Association for the Advancement of Automotive Medicine, 2008.

12. Nuyttens N, Belleghem GV, Dupont E, Leblud J, Devos $\mathrm{S}$, Putman $\mathrm{K}$, et al. The maximum abbreviated injury scale as a predictor of severe/fatal injuries in Belgian Road victims. Injury Prevention 2016; 22 (Suppl 2): A318.

13. Clark DE, Black AW, Skavdahl DH, Hallagan LD. Open-access programs for injury categorization using ICD-9 or ICD-10. Inj Epidemiol 2018; 5(1): 11.

14. Road Traffic Safety Agency of the Republic of Serbia (RTSA RS) Project: System for recording data on injuries in traffic accidents in accordance with the recommendations of the European Commission. Belgrade: Faculty of Transport and Traffic Engineering, University of Belgrade, 2017. (Serbian)

15. Andjelic S, Colakovic G, Lipovac K, Pesic D, Plemic Z, Smailovic E. Comparative Analysis of Injury Severity Caused by Traffic Accidents Classified as Severe Injury in Police Databasevs. MAIS 3+ Injury in Hospital Database - First Pilot Research in Serbia. Signa Vitae 2020; 16(1),13-24.

16. Broughton J, Keigan M, Yannis G, Evgenikos P, Chaziris A, Papadimitriou E, et al. Estimation of the real number of road casualties in Europe. Saf Sci 2010; 48(3): 365-371.

17. IRTAD. Reporting on Serious Road Traffic Casualties: Combining and using different data sources to improve understanding of non-fatal road traffic crashes, International Traffic Safety Data and Analysis Group, OECD/ITF, Paris, 2011.

18. High-level group on road safety consultation on the development of the injuries strategy. $2^{\text {nd }}$ Working Document: Next steps in the development of the injuries strategy, 2012. 